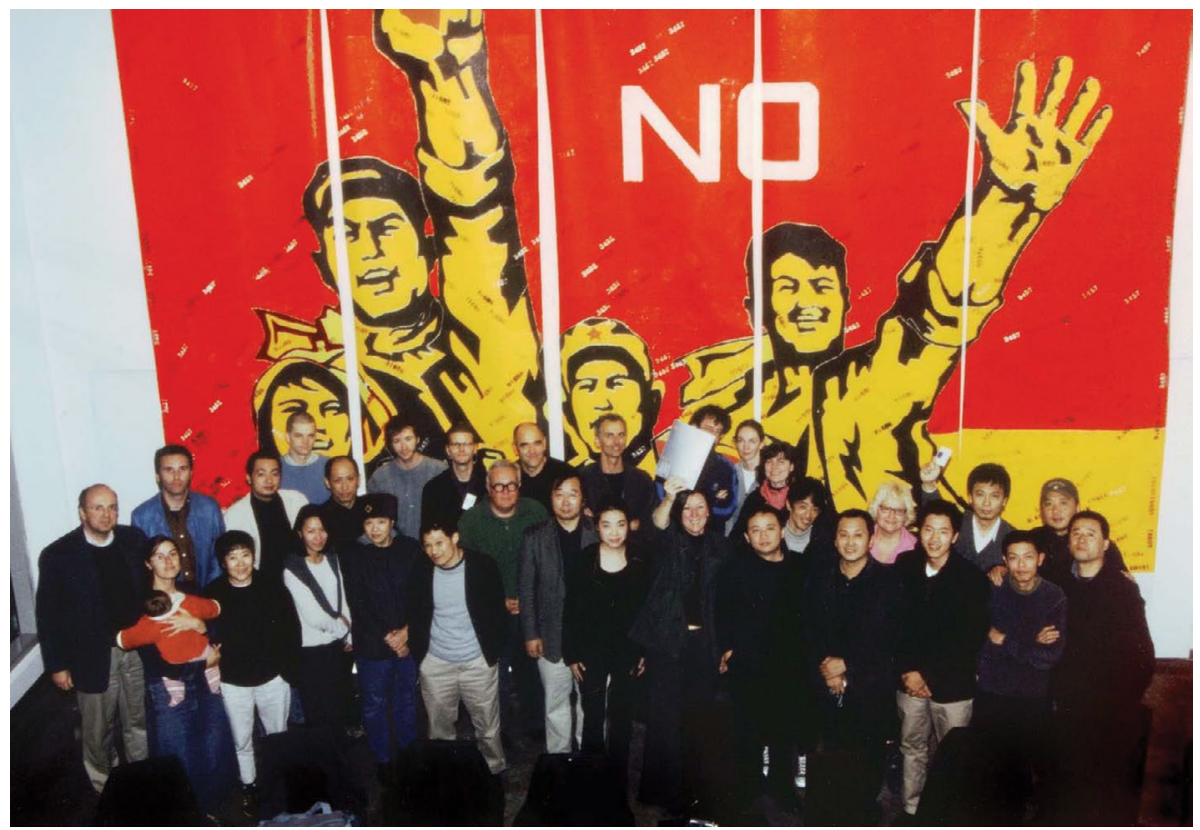

Group photo after MAAP in Beijing-Moist opening, 2002. The dinner at Chama Gundao restaurant was generously sponsored by the owner, Chinese artist Fang Lijun. Front row from left: Young-Hae Chang (2nd), Marc Voge (5th), Jin Hua (6th); from right: Kim Machan (6th), Pi Li (5th), Wang Gongxin (4th), Paul Bai (3rd), Chen Shaoxiong (2nd), Zhang Peili (1st). Back row from left: Johan Pijnappel (1st), lan Mott (2nd), Alex Galloway (4th), Ma Gang (5th), Tim Plaisted (6th), Peter Callas (8th), Bernd Lindermann and Manfred Wolf-Plottegn (7th \& 9th), Stuart Coop (10th); from right: Wang Peng (1st), Zhu Jia (2nd), Takuji Kogo (4th), Julianne Pierce (5th) and Justine Cooper (6th).

2002年“润化” 参展艺术家及相关人员集体合影。摄于茶马古道餐厅, 晚餐由餐厅东主及知名艺术家方力钧先生慷慨赞助。前 排左起：张英海（第二），马克 ·沃治（第五），晋华（第六），前排右起：金曼（第六），皮力（第五），王功新（第四） , 白浦（第三）, 陈劭雄（第二），张培力（第一）。后排左起：约翰 ·潘艾珀（第一），伊恩 ·莫特（第二），阿莱克斯 · 加洛维（第四），马刚（第五），送姆 - 普拉斯特德（第六），皮特 · 卡拉斯（第八），本德 · 林德曼与曼费伊德 ·沃夫 ·普 罗特根（第七，九）, 斯图沃特 ·库普（第十）；后排右起：王蓬（第一), 朱加（第二），古乡卓司（第四），朱莉安 ·皮叶斯 及佳丝汀・库玻（第六）。 


\section{On curating media art between China and Australia since the 1990s}

\section{Kim Machan}

The news that Zhang Peili's painting Flying Machine (1994) had been donated to the Australian Centre on China in the World (CIW) was remarkable, not only because of the finite number of paintings that Zhang produced in the 1980s and early 1990s, but also because this particular painting had never been exhibited and was said to have been lost. ${ }^{1}$ Adding to its exclusive nature, the work is one of the last paintings the artist made before turning to concentrate on video and electronic media; it is therefore a significant transitional marker in his practice. There was clear logic, then, in preparing a proper context for the painting's arrival in Canberra. The exhibition Zhang Peili: From Painting to Video activated several well-known video artworks to bracket the painting, with one work preceding the painting by six years, while others were as recent as 2012 .

To expand the context of this exhibition, I would like to describe some early art exchanges and experiences I had in China as a curator of video and media art. While this certainly isn't a full or systematic account of events, it is an attempt to sketch a backstory reminding us that exhibitions are much more than temporal events or products: exhibitions are resting points in shared conversations and relationships. Here, Zhang Peili's practice is brought into focus not only to share his artistic accomplishments but also to counter a recurrent amnesia patterning overlooked histories of artistic exchange between China and Australia. This account goes some way in explaining how the artworks in Zhang Peili: From Painting to Video were eventually assembled; how previous large museum projects in China thread into new, concentrated and challenging curatorial 
projects in Australia; how the flow of art and artists between China and Australia has been steadily navigated; and how the existing works of an artist like Zhang Peili can be read in new contexts and new iterations.

My first exposure to Zhang Peili's work in an exhibition was in 1999, at the Third Asia Pacific Triennial of Contemporary Art, at the Queensland Art Gallery, in Brisbane. With his painting practice having already been shelved for five years, the work Endless Dancing (1999) demonstrated his sculptural, cool and interrogative approach to media and subject. ${ }^{2}$ Stepping inside the circle of eight monitors was a compelling experience, and a strong vector to an area of conceptual video art practice that I would soon follow back to China. These were early days, when it was still uncommon to see Chinese video and media art practice, not only overseas but in China, too. There were few opportunities to view video art at exhibitions, making studio visits and artists' networks the best entry points into the field. In Australia, however, there were chances to see some of Zhang Peili's first video works. For example, Zhang's single-channel video Document on Hygiene No. 3 (1991) and his early video installation Operation No. 1 (1992) were brought to Australia in the 1993 exhibition Mao Goes Pop, at the Museum of Contemporary Art, Sydney. ${ }^{3}$ The next opportunity was in the 1998 Sydney Biennale, curated by Jonathan Watkins, who included the three-channel video installation Eating (1997). ${ }^{4}$ In late 1997, Eating became the first contemporary artwork by a Chinese artist to be acquired by the Museum of Modern Art (MoMA), New York. ${ }^{5}$

In 2000, an international masterclass of new media art was held in Brisbane for artists and curators to exchange ideas, present work and develop collaborations. ${ }^{6}$ Although Zhang Peili was not involved, another Chinese artist working conceptually with video art and installation was. Wang Gongxin's critical approach and insider position were evident in his first-hand accounts of Chinese art and artists. He shared his excitement about the emerging 'new media' art scene, including Zhang Peili's work, and the department of new media that Zhang had been asked to establish at the China Academy of Art, in Hangzhou. This developing rapport was also greatly enhanced by the presence of Brisbanebased Chinese Australian artist Paul Bai. Where language or meaning might have been uncertain, Bai from that time forward participated in the unfolding relationships and projects, enabling clear understanding and a sense of trust. 
Wang Gongxin returned to Beijing in June 2000 and enlisted the then emerging Chinese curator $\mathrm{Pi} \mathrm{Li}$ to curate a video programme for the annual arts festival of MAAP (then known as Multimedia Art Asia Pacific); the festival was scheduled to open just three months later, at the Brisbane Powerhouse Centre for Live Arts. ${ }^{7} \mathrm{Pi}$ swiftly freighted his selection of single-channel videos and interactive CD-ROM works to Brisbane. Remarkably, over half of the programme had been completed that year, some works just weeks before being screened in Brisbane. For a number of works, it was the first time they would be screened outside of China. The single-channel works included Lady's (2000) by Cui Xiuwen, Fly Fly (1997) by Jiang Zhi, City Light (2000) by Yang Fudong, Ping Pong (2000) by Qiu Zhijie, Ma Gen Ma (2000) by Feng Xiaoying, Related to the Situations (1999) by Hu Jieming, Body (2000) by Wu Ershan, and Fly (1999) and Karaoke (2000) by Wang Gongxin. In hindsight, perhaps even more impressive was the inclusion of interactive CD-ROM works such as West West (2000) by Qiu Zhijie, Landscape III (1999) by Chen Shaoxiong and Seven (2000) by Shi Qing, all of which are seldom seen today. The works that would be compiled in Brisbane arrived individually in a wide assortment of VHS tapes, mini-DV cassettes and CD-ROM discs. While a bulky package of electronic files by today's standards, the portability of video was then revolutionary, and responded perfectly to many artists' drive to have their work seen outside of China.

In April 2001, I travelled to China on a mission to return the artists' works and conduct research through studio visits in Beijing, Shanghai and Hangzhouthe last specifically to meet Zhang Peili. ${ }^{8}$ The trip was an opportunity to see as much work as possible at a time when exhibitions were generally held at short notice, in unexpected venues and sometimes for only a day or two. The Ministry of Culture had just issued a decree to all local authorities to crack down on exhibitions and performances that were 'disturbing social order, public morality, and the spiritual health and physical health of the people'. ${ }^{9}$ The general political mood was quite tense, particularly in Beijing; it was the year leading up to the anticipated decennial leadership transfer of presidential power, in this case from Jiang Zemin to Hu Jintao.

Beginning in Beijing, I was able to meet Pi Li for the first time, as well as many of the artists who had exhibited work in Brisbane. Besides returning their works, I had been invited by Wang Gongxin to present Australian video artworks at the Loft New Media Art Space, ${ }^{10}$ a chic and somewhat clandestine backroom space within the Loft restaurant, a contemporary New York-style establishment 
in Sanlitun, Chaoyang District. This highly active venue held exhibitions, talks and publication launches; it hosted curators, artists, theorists, writers and experimental musicians, both local and international. It was the kind of venue where artists and those interested in art could be assembled at short notice, for a screening or for a talk by a guest from out of town or overseas who may not have pre-announced their visit. Thanks to Wang Gongxin's networks, the audiences at the Loft were highly relevant and attentive, and often surprisingly large. The great energy and sense of urgency in the contemporary art community in Beijing were also apparent, though expressed differently, in Shanghai and in Hangzhou, the city where Zhang Peili lived, worked and taught. While Beijing pulsed with ambitious artists and a sense of danger from the authorities, Shanghai's mercantile characteristics seemed to overshadow art, whereas Hangzhou had a feeling of remoteness and autonomy.

It was in late April 2001 that I first visited Zhang Peili's Hangzhou studio, to view back-to-back single-channel videos. I can still recall the sensation of this first viewing, progressing chronologically, cartridge by cartridge, through Zhang's library of works, the moving image produced by a chunky CRT monitor connected to a rather ordinary VHS unit that gobbled, played and spat out the tapes in succession. I remember being surprised by $30 \times 30$ (1988) and mesmerised by Document on Hygiene No. 3 (1991). The works continued: Water: Standard Version from the Cihai Dictionary (1991), Focal Distance (1996) and Uncertain Pleasure I (1996) -the last, a four-channel, twelve-monitor work, shown in sequential samples on a single monitor. Although I wasn't able to speak Chinese, Zhang Peili patiently showed me sketchbooks with diagrams of how the works should be installed, and was extremely hospitable and generous with his time.

After viewing the works in Zhang's studio, we went to the China Academy of Art, where he was establishing the New Media Art Centre, and there I was introduced to video curator Wu Meichun. ${ }^{11}$ Besides being the co-curator, with Qiu Zhijie, of Image and Phenomenon in 1996-considered China's first video art exhibitionWu would later become the centre's director. ${ }^{12}$ I had already heard of $\mathrm{Wu}$, having met with Qiu Zhijie in Beijing, earlier in the research tour, where he gave me publications they had produced that translated key texts about the history of video art. Qiu also mentioned their collaborative curatorial work on video art projects in Hangzhou and his increasingly outrageous 'happenings' created under the banner of 'post-sensibility' in Beijing. 


\section{Focal distance}

As a result of this research tour, Wu Meichun's video programme was exhibited in MAAP's Excess media art festival, at its main venue, the Brisbane Powerhouse, in October 2001. ${ }^{13}$ The programme included Zhang Peili's Focal Distance (1996), presented as I had previewed it in his studio, as a singlechannel work, though conventionally known as an eight-channel monitor installation. Focal Distance and Yang Zhenzhong's single-channel video I Will Die (2001) were exhibited on separate, dedicated CRT monitors, set on plinths, looped to play continuously in the public lounge areas of the Powerhouse's riverside building. Wang Gongxin returned to Brisbane to attend the opening and to install two of his works: The Prayer (2001), a single-channel video projection, also in the Powerhouse, and My Sun (2001), a three-channel video projection, at the Judith Wright Centre of Contemporary Arts, with the support of the Institute of Modern Art.

During this visit, Wang Gongxin optimistically encouraged me to move the MAAP festival to Beijing the following year. He believed it would be possible to realise the exhibition with local institutional support, and even direct sponsorship from the Chinese government, through the Chinese International Exhibition Agency-and this was the case. I assumed the underlying reason for official support was the Chinese government's aspiration to participate in all aspects of the international transformation of global economies through digital culture. Promoting China's progressive contemporary digital and new media culture was just as important as promoting other tech-savvy sectors, such as medicine, transport, energy and space exploration. Considering the open conflict between artists and the government, both sides were motivated to collaborate under the banner of new media art. Zhang Peili was by this time working exclusively with video and new media platforms, though, as revealed in many interviews and conversations, he was interested in a way to break free of subjectivity, and to explore and experiment in other media. This interest saw many of Zhang Peili's video installations reinterpreted and modified as technologies evolved; some works were updated with new hardware and software enabled by digital file formats.

\section{Broadcasting at the same time}

Zhang Peili was one of the first artists confirmed to produce a project for the MAAP in Beijing 2002: Moist media art exhibition, which eventually took place in October 2002, at the Art Museum of China Millennium Monument. ${ }^{14}$ With 
the help and guidance of Wang Gongxin, Pi Li, Fan Di'an, Li Taihuan and Wang Yudong, the first major museum exhibition and symposium of new media art in China were brokered, expanding exhibition contexts and improving exhibition technical support for artists. ${ }^{15}$ Besides the 1,000-square-metre main exhibition space, a unique feature of the Millennium Monument was a screen comprising fifty-six LCD monitors, stacked four high and fourteen across, curving in a thirty-one-metre-long arc, forming the largest high-definition screen in China at the time. Recognising its potential, Zhang experimented with the technology, reprogramming an existing work to insert an Orwellian cacophony into a most symbolic and significant building. Broadcasting at the Same Time (2002) played through a chequerboard wall of newsreaders, switching in and out as they announce their equivalent of 'Good morning, this is the news', sampled from over fifty countries, in a cross-hatched myriad of languages. The sea of voices played through the state-of-the-art sound system, combined with the array of faces and the overwhelming screen size, was dizzying, comical and ultimately ominous. In the original work, made two years earlier, twenty-six inward-facing monitors form a circle, surrounding the viewer with the newsreaders' greetings. Serial formats are often employed in Zhang Peili's work; whether in a circular or linear space, whether circular or linear in time, the rules are applied and repeated to deconstruct and reconstruct language, imagery and meaning. His work at the Millennium Monument was no exception.

During the official opening days in Beijing, I was asked to conduct guided tours, initially for officials from the Ministry of Culture but subsequently for a surprising collection of other officials as well. I recall conducting a succession of tours with six to eight people in each, introduced as being from the Ministries of Communication, Science, Health and Transport, among others. A remarkable opportunity for cultural diplomacy had appeared; however, because there had been little notice before the entourage of high-level government representatives arrived, their Australian counterparts were unfortunately absent.

To bring further context to the exhibition in Beijing, it is useful to bear in mind the status quo. At that time, the Chinese government, through the Ministry of Culture, closely monitored public exhibitions, requiring state-run institutions to submit detailed applications - providing images and text for all exhibiting artists and their works - before approval could be granted for an exhibition. ${ }^{16}$ It was well known that government sensitivities towards artistic expression were strongest in Beijing; cultural activities in cities to the south such as Shanghai, Hangzhou 
and Guangzhou enjoyed more relaxed conditions. The MAAP in Beijing 2002: Moist exhibition embodied an important moment: it was able to inhabit a firsttier government-approved exhibition space with artworks that greatly extended the parameters of accepted art practice in China. This was, after all, the very monument that Jiang Zemin had constructed during his presidential term to be the domestic and international focus of China's millennial celebrations, and which he personally unveiled just before midnight on 31 December 1999.

Zhang Peili's wall of high-definition monitors was one of a raft of experimental digital media artworks in the exhibition. Another using the same wall was the Web of Life (2002) by Jeffrey Shaw and others. ${ }^{17}$ Through the interactive process of scanning the viewer's hand, an algorithmically selected sequence of images was generated across the fifty-six-monitor screen. The first live internet artwork seen in a museum setting in China, this was networked with ZKM in Karlsruhe, ISEA in Nagoya and Emoção Art.ficial in São Paulo. Call 13641041729 (2002) by Wang Peng adopted a different approach to network technology by inviting the audience to telephone the eponymous mobile phone number, thereby activating a data projector suspended above Wang's gourd-shaped sculpture in the museum. When the number was called, a series of everyday Chinese streetscapes and landscapes were projected within the sculpture while the caller listened to the artist's recorded message, which included an invitation to leave a message in return. Twenty other immersive and challenging works from Asia and Australia were presented, with screening programmes from the Australian Centre for the Moving Image, dLux MediaArts, Asialink and the Hong Kong-based Videotage. ${ }^{18}$ All artworks were submitted to and approved by the Ministry of Culture, except for one video that inadvertently included brief footage of a Falun Gong exercise display. When the exhibition opened, it was difficult to believe that just four years earlier, state-run exhibitions could not or would not deviate from the accepted definition of art as a painting on a wall or a sculpture on a plinth. ${ }^{19}$

Although not in a public space or museum, a new media art exhibition from Australia found an inventive platform that bypassed official process. In 1999, Linda Wallace curated six Australian artists into a new media art exhibition titled Probe, ${ }^{20}$ at the Australian embassy in Beijing, supported by embassy Cultural Counsellor Anthony Taylor and Australian gallerist Brian Wallace $^{21}$ and encouraged by Geremie Barmé. The exhibition was mounted in the foyer of the embassy, allowing access through a ticketed invitation that was recycled many times over to an eager Chinese audience. ${ }^{22}$ Outside state-run institutions, performance, installation art, and video and media art 
continued to push boundaries, eventually triggering another formal government crackdown in early $2001 .{ }^{23}$ Despite these restrictions, which led to provocative exhibitions being closed and artists being arrested or detained, the concept of new digital technologies applied to contemporary art was, we were told, considered through a different lens by the government. After the 2002 MAAP in Beijing: Moist new media art exhibition and symposium, the Art Museum of China Millennium Monument continued to emphasise new media art, partnering with curator, educator and artist Zhang Ga to produce the Beijing International New Media Arts Exhibition and Symposium in June 2004, at which I presented some MAAP projects. ${ }^{24}$

In March 2005, Zhang Peili returned to Australia to present two works, on an invitation from the then director of the Institute of Modern Art, Michael Snelling. ${ }^{25}$ In Brisbane, Zhang installed two single-channel projections, Actor's Lines (2002) and Last Words (2003), in the main gallery. This became another opportunity for us to meet, without any specific project in mind; and although we met regularly in different exhibition contexts in China and internationally, it would be four years before concrete plans began for another project.

\section{Standard translation}

In 2010, I invited Zhang Peili to produce a site-specific installation in the context of selected public libraries in Australia and China, as part of the project Light from Light (2010-12). This project invited five Australian and five Chinese artists to create works that would be installed in the State Library of Queensland, in Brisbane; the Shanghai Library; the National Library of China; the National Art Museum of China, in Beijing; and the Hangzhou Public Library. ${ }^{26}$ After considering and responding to the library sites, Zhang decided to revise Standard Trans/ation (2008), originally a 4:3 single-channel video work, using newly available hardware and software. Under the same title, the new work (2008-10) transformed the earlier video concept into a custom-built two-metre-long scrolling-text LED monitor, a medium that evokes authoritative news headlines and didactic stockmarket information. ${ }^{27}$ The development of the work and the exhibition tour kept communications and meetings frequent, including travel by Zhang to Australian and Chinese venues.

At the State Library of Queensland, Zhang's monitor replaced the existing redtext LED news monitor in the Tim Fairfax Newspaper Reading Room. In Beijing, at the National Library of China, the work operated for the duration of the 
exhibition atop a prominent though nondescript bookcase to confound and inspire researchers in periods of procrastination or contemplation. The project brought Zhang to Brisbane in September 2010 to work with technical staff at the library, to participate in a symposium and to refine the installation. $\mathrm{He}$ also travelled to Beijing, for the opening at the National Library of China, and to the Shanghai and Hangzhou libraries, to direct the installations. Australian artists Janet Burchill, Jennifer McCamley, Paul Bai, Eugene Carchesio, Joyce Hinterding, David Haines and Archie Moore and Austrian artist Josef Strau travelled to Shanghai for the installation and, later, to present at an exhibition symposium arranged with the support of Zhang Peili at the China Academy of Art, Hangzhou. The artists toured the art school and presented their individual works and practice at the symposium. In addition, I offered a curatorial exhibition overview to a symposium audience, predominantly students.

Through this extended contact during the two-year tour of Light from Light, Zhang and I discussed the possibility of presenting a solo exhibition in Australia. In 2012, when MAAP was opening a new exhibition venue in Brisbane, MAAP SPACE, he agreed to present his work as the opening exhibition. In August 2012, he returned once again to Brisbane to direct the installation of his works, and also generously presented an artist's talk during the first few days of the exhibition. Zhang's solo exhibition included seminal works I had seen in our first meeting in 2001$30 \times 30$ (1988), Document on Hygiene No. 3 (1991) and Uncertain Pleasure I (1996) - and Standard Translation (2008-10), which had been in storage in Brisbane since the end of Light from Light. MAAP SPACE also showed a new work, $Q \& A \& Q$ (2012), the first time it had appeared in a gallery or museum. ${ }^{28}$

\section{$Q \& A \& Q$}

This synchronised two-channel video installation is projected into a corner of the gallery, with head-and-torso portraits of an interrogating policeman on the left screen and sequential interviews with two detained petty criminals on the right. The formal, perpendicular placement of each screen is triangulated with a simple hard bench that places the viewer as a central witness to the volley of questions and answers across the implied table. The footage was recorded by two cameras centred on the table, facing in opposite directions, to record each figure individually. Zhang Peili's characteristically neutral approach attempts to present the exchange as realistically as possible. The artist describes the work as a 'Question \& Answer conversation recorded by ... installed equipment between two persons, who have opposing identities', and confirms 'it is neither CCTV, nor 
is it a manipulated recording'. ${ }^{29}$ This is not a rehearsed drama, but nor is it secretly filmed; there is a level of self-consciousness in both the police interviewer and the suspects being interviewed, which Zhang judges to be a better way to achieve a kind of realism. ${ }^{30}$

I returned to China in May 2013, bringing with me the package of DVDs to return to Zhang Peili personally. When I handed over this substantial collection and thanked him for his participation and continued support, Zhang pushed the works back to me, saying, 'You should take these back with you; you might need them.' For me, this was a memorable gesture of trust, as well as, perhaps, a challenge to make another project. The works were securely stored, and it was not until discussions with Olivier Krischer about making an exhibition at the CIW that this significant collection of works began once again to stir and inspire.

Immediately preceding the CIW project was another exhibition on which Zhang and I collaborated between 2013 and 2015. LANDSEASKY: Revisiting Spatiality in Video Art (2014-15) was a touring exhibition that evolved with founding support from OCAT Shanghai and further support from the Art Sonje Center, in Seoul; the Guangdong Museum of Art, in Guangzhou; the National Art School Gallery, in Sydney; Griffith University Art Gallery; and MAAP SPACE, in Brisbane. The curatorial focus was on sculptural and spatial approaches to video by selected Australian, Chinese and other international artists, taking as a reference point the international ('global') dialogue in conceptual art practices of the 1960s and 1970s. ${ }^{31}$ The exhibition opened in Seoul in February 2014 with the support of Sunjung Kim at the Art Sonje Center and local satellite commercial art gallery spaces, before travelling to OCAT Shanghai in April. Zhang Peili was one of the artists who joined the project as it developed, with his work The Distance of One Kilometre (2010), a two-channel video installation showing two people holding a video camera, walking towards each other in a straight line from a distance of one kilometre until they meet. Additional electronic hardware interfered with the standard recording signal to increasingly distort the visual and audio recording of their approach, resulting in a crescendo of blinding and deafening white noise. ${ }^{32}$ The exhibition concluded at the Guangdong Museum of Art in May 2015. ${ }^{33}$

\section{Zhang Peili: From Painting to Video}

Now we return to the 'resting point in our shared conversation': the exhibition at CIW that was inspired by the revelation of a painting thought to have been lost. The exhibition brought colleagues to Canberra in August 2016, to once again 
meet with Zhang Peili and to appreciate the depth and multiple facets of this long relationship with the artist. Lois Conner, Geremie R. Barmé, John Clark, Claire Roberts, Paul Bai, Katherine Grube, Olivier Krischer and I joined Zhang in the opening celebrations of his exhibition. Zhang also gave the keynote address, ably translated by novelist and cultural critic Linda Jaivin, for a parallel conference organised with the ANU School of Art, titled Moving Image Cultures in Asian Art. ${ }^{34}$

The first work encountered in the CIW exhibition, Uncertain Pleasure I (1996), has been presented in various configurations since it was first displayed at Galerie de France, Paris, in 1996. This six-channel work is duplicated across twelve monitors and always specifically arranged to suit the exhibition. ${ }^{35}$ At CIW, eight monitors were positioned within the gallery, with four monitors outside, as if the dividing glass entrance doors were of no consequence. Sliding through the verge of the gallery, the work broke into the public foyer, emphasising the spatial experience of Zhang's video artwork. The physical positioning of Uncertain Pleasure inside and outside the gallery activated an awareness of other boundaries and thresholds, signalling the inclusion of other, incidental views through the gallery's north-facing glass wall: the expansive grounds, the Australian native shrubs, the mature gum trees and Sullivans Creek. Placing the monitors on the ground, fanning out into the foyer, allowed sight lines to other works within the gallery space. From the entry foyer, looking over the dozen monitors showing the iconic skin-scratching imagery, the luridly coloured sliding text of Standard Translation could be seen in the background, perched high on the dark-grey back wall.

Noticeable also from the entry was the incandescent 'video blue' background behind the newsreader in Water: Standard Translation from the Cihai Dictionary (1991), set on a plinth against the left wall and indirectly facing the painting Flying Machine (1994). The hard-edged helicopter shape in Flying Machine is surrounded by a very similar blue, making a palpable link between the artist's representation of Chinese official-media imagery in video and in this painting made three years later. The identity of the helicopter in Flying Machine is indeterminate, though the shape looks to be transposed from a newspaper photo or television footage. Zhang again provokes questions about how reality is represented in television and print media, with each work seeming to adopt official media templates, though emptied of practical information and original subjectivity. The painting was hung in a section of the gallery with a relatively low ceiling height and in contrast to the grey walls, the surrounding section of this wall was painted white, intensifying the brightness of the blue. Closely examining the painting's surface, one can identify the brush work and masking technique that is used to articulate 
the shape of the 'flying machine'. It occurs to me that the treatment of paint in this work is uncommon in comparison to his Swimmers (1985), the saxophone player in Musical Pause (1985) or the $X$ ? series of glove paintings (1986-87). Rather than the very flat and often thin appearance of paint in these works, the helicopter shape is patterned with an accumulation of informal drips and splashes of paint, evidencing an abstract impulse, only to be reined back to reinstate a 'neutral' subjectivity by masking the outlined shape of a helicopter and painting the surrounding canvas, to the limits of the painting, flat blue-a rare technique in Zhang's painting practice.

Beyond the monitors of Uncertain Pleasure and the brightness of Flying Machine, the sight of a modest twenty-four-inch CRT monitor on a plinth drew you further into the gallery, to $30 \times 30$ (1988), Zhang's first use of video. The audio was set low, without headsets, coexisting with the louder, stern audio feed from Water: Standard Translation from the Cihai Dictionary nearby. We chose to display these works on modestly sized monitors, in keeping with the original technology and sympathetic to the gallery's dimensions. Turning to the right, the view down the end of the gallery rested on yet another twenty-four-inch CRT monitor offering a glimpse of Document on Hygiene No. 3 (1991). As this work has no sound its proximity to the entrance of the last work in the exhibition, $Q \& A \& Q$, posed no conflict; in fact, the control and ultimate submission of the repeatedly washed and rinsed chicken spoke thematically to the issues of control and submission within the repetitive interrogation sequences of $Q \& A \& Q$. Behind the wall that supported Document on Hygiene No. 3's simple plinth and monitor was the final exhibition room. Two simple wooden chairs faced the corner where the twochannel projection $Q \& A \& Q$ looped endlessly, with the audio playing from speakers. This final work completes the exhibition context that supports Zhang Peili's painting Flying Machine in the Canberra setting.

In this way, the origins of Zhang Peili: From Painting to Video can be traced across three decades, involving a cohort of artists, curators and academics in uncalibrated waves of meetings, exhibitions and relationships with the artist and many of his peers. Our intermingled stories, at once professional and personal, combine to make a particular account of cultural exchange, collaboration and friendship. 
1 Huang Zhuan and Jing Wang, eds., Zhang Peili: Yishu gongzuo shouce [Artistic Working Manual of Zhang Peili] (Guangzhou: Lingnan Meishu Chubanshe, 2008), 184-85.

2 This installation displayed the scene of ballroom dancers from eight fixed camera positions filmed from outside the dance floor; the imagery is turned in on itself by playing that vision on the eight monitors turned to the inside of the circular formation. Commissioned and acquired by the Queensland Art Gallery for the Third Asia Pacific Triennial, in 1999, this work was also exhibited in the Zhang Peili: Record. Repeat. solo exhibition at the Art Institute of Chicago in 2017.

3 Mao Goes Pop: China Post-1989 at the Museum of Contemporary Art (MCA) was the smaller, Sydney iteration of the exhibition China's New Art, Post-1989, principally organised by Beijing critic Li Xianting and Hong Kong gallerist Johnson Chang Tsong-zung, held at the Hong Kong City Hall and Hong Kong Arts Centre between January and February 1993, as part of the Hong Kong Arts Festival. Sydney was the first overseas destination for the show, which then toured to Melbourne, Vancouver and five venues across the United States. In Sydney, the writer Nicholas Jose, who had been Australia's cultural counsellor in Beijing between 1987 and 1990, acted as curatorial advisor to the MCA.

4 Jonathan Watkins, an art history graduate of the University of Sydney, travelled to China in 1997-98 to research artists, with the support of the critic Huang Du. Jonathan Watkins, email to author, 11 July 2017.

5 This followed from MoMA curator Barbara London's September 1997 research trip to China, for which she made a blog titled Stir-Fry: A Video Curator's Dispatches from China. See www.adaweb.com/context/stir-fry/ index1.html. MoMA then held Zhang Peili: Eating to exhibit the work, 28 October 1998-2 February 1999. The museum also acquired Document on Hygiene No. 3 (1991), possibly in 1998. See www.moma.org/documents/ moma_press-release_386972.pdf.

6 Australian Network for Art and Technology (ANAT) director Amanda McDonald Crowley organised the event, held from May to early June 2000, which included fifty-eight artists, tutors and curators from Europe, North America, Asia and Australia. I participated as an invited curator. Wang Gongxin was the only artist from China, but among other Asian artists were Shilpa Gupta and Monica Narula from India, Partha Pratim Sarker from Bangladesh, and Hartanto and Christiawan from Indonesia.

$7 \mathrm{Pi} \mathrm{Li} \mathrm{completed} \mathrm{his} \mathrm{doctorate} \mathrm{in} 2010$ at the Central Academy of Fine Arts, in Beijing. He was then curator and gallerist at Boers Li Gallery, Beijing, from 2005 to 2012. In July 2012 he became senior curator at the M+ Museum of Visual Culture, Hong Kong.

8 This was the preferred method for returning artworks, to reduce freight complications with customs.

9 Thomas J. Berghuis, Performance Art in China (Hong Kong, Timezone 8, 2006), 274-75.

10 The Loft New Media Art Space had been operating for just eight months, having opened on 10 August 2000 with an installation by Gu Dexin. An account of projects and proposals are documented in the self-published booklet Welcome to the Loft (2002), as a special project for the 2002 Gwangju Biennale. The programme in this booklet was curated by Wang Gongxin and Pi Li, with an additional text from Lin Tianfang.

11 Image and Phenomenon was held in a gallery space at the China Academy of Art on 14 September 1996, featuring video works by fifteen artists, most of which were multi-channel installations.

12 Zhang Peili established the New Media Art Centre at the China Academy of Art in 2001. The first students were enrolled in 2003, and Zhang worked closely on curriculum development throughout 2004 and 2005. The first class of new media art students graduated in 2006.

13 For details of the special screening programmes and video installations that were also presented, see www. maap.org.au/exhibition/maap-2001-excess.

14 Produced by MAAP in partnership with the Art Museum of China Millennium Monument, the Beijing Gehua Cultural Development Group, the China International Exhibitions Agency, the Central Academy of Fine Arts and the Australian embassy in Beijing.

15 Besides the independent artist, Wang Gongxin, Pi Li was then an assistant researcher at the Central Academy of Fine Arts (CAFA), Beijing; Fan Di'an was vice president of CAFA; Li Taihuan was artistic consultant for the Chinese International Exhibitions Agency; and Wang Yudong was vice director of the Art Museum of China Millennium Monument. Organisational support also came from Linda Hao, a cultural relations officer at the Australian embassy.

16 The process of gaining permission from the Ministry of Culture is ongoing; in fact, with advancing technology it is widening to include further venues open to the public. 
17 Other artists and contributors to the Web of Life were Michael Gleich, Bernd Lintermann, Torsten Belschner, Lawrence Wallen and Manfred Wolff-Plottegg. Lintermann and Wolff-Plottegg travelled to Beijing to install the work as well as to participate in the symposium and related events.

18 For the catalogue of art works, screenings, residencies and related events at the Art Museum of China Millennium Monument and the Loft New Media Art Space, see www.maap.org.au/publications/\#moi.

19 After the 1989 exhibition China/Avant-Garde at the National Art Museum of China in Beijing, there would be restrictions avoiding the presentation of Chinese contemporary art in state-run museums until 1998.

20 Linda Wallace was a PhD student at The Australian National University and this exhibition was an outcome of that research. On Wallace's practice as a video artist and curator, including her work in Asia, see www.machinehunger.com.au/new.html and www.scanlines.net/person/linda-wallace (which includes video clips).

21 Brian Wallace first travelled to Beijing in 1984, returning in 1985 and eventually staying on to work and study, including earning a degree in art history from the Central Academy of Fine Art. In 1991, he opened the first foreign-owned contemporary art gallery in Beijing, Red Gate Gallery, which was initially in the China World Trade Hotel, before moving into the Ming-dynasty era Dongbianmen watchtower, one of the few remaining buildings from Beijing's city walls.

22 This more relaxed access to the Australian embassy changed after the September 11 attacks in New York, and the subsequent proclamation of a war on terror. For exhibition details, see www.machinehunger.com.au/probe.

23 Berghuis, Performance Art in China, 274-75.

24 Zhang Ga, then based in New York, was teaching at the Parsons New School of Design. In 2008, the exhibition evolved into the Beijing International New Media Biennial, moving to the National Art Museum of China with the support of its director, Fan Di'an. MAAP partnered with the project, presenting Australian artists Stelarc and Transmute Collective, as well as Kim Kichul from Korea and Paul Lincoln from Singapore. In 2011, it became the International Triennial of New Media Art. MAAP again partnered with the 2014 edition, Thingworld, supporting projects by Australian artists Wade Marynowsky, Keith Armstrong, Lawrence English, Petra Gemeinbach and Rob Saunders.

25 Communications to support this invitation were assisted by MAAP and Paul Bai.

26 This public art project was awarded the Australian Ministry of Arts inaugural Australia Arts in Asia AwardVisual Art in 2013. For the exhibition catalogue, see www.maap.org.au/publications/\#Ifl.

27 The LED messages, displayed in an array of lurid colours that are intentionally uncomfortable to read, are generated by a 2010 version of Google Translate software. The original or source text, the Chinese proverb hao han bu chi yan qian kui 好汉不吃眼前亏, which refers to having the wisdom to retreat from otherwise certain defeat in battle, is translated into English by the software to read 'Heroes do not eat the immediate loss'. In this way, the proverb is systematically misrepresented and degraded through more than twenty-five languages.

28 Boers-Li Gallery in Beijing had shown this work at Art Basel, Switzerland, earlier that year. After MAAP's exhibition in August, it was exhibited at the Shanghai Biennale, from 2 October 2012.

29 Zhang Peili, artist's statement, in the catalogue to the Ninth Shanghai Biennale (2012), the first year it was held at the Power Station of Art. In Li Xianyang and Xu Jiang, eds., Reactivation: 9th Shanghai Biennale: DS Inter-city Pavilion Project (Shanghai: Power Station of Art, 2012), 138.

30 Zhang, artist's statement, 138.

31 Artists included Jan Dibbets (Netherlands); Yang Zhenzhong, Wang Gongxin, Wang Peng, Zhu Jia and Zhang Peili (China); Kimsooja, Yeondoo Jung and Sim Cheol-Woong (South Korea); Paul Bai, Lauren Brincat, Barbara Campbell, Derek Kreckler and Craig Walsh (Australia); Giovanni Ozzola (Italy); João Vasco Paiva (Portugal / Hong Kong); Shilpa Gupta (India); and Heimo Zobernig (Austria). Curator Kim Machan. Full details of the project are available at www.maap.org.au/exhibitions. The catalogue is also online: www.maap.org.au/publications/\#lss.

32 This work was commissioned for the exhibition Not Only Time: Zhang Peili and Zhu Jia, at REDCAT, Los Angeles, but was titled One Line, One Kilometer in the exhibition brochure: www.redcat.org/sites/redcat.org/ files/gallery/linked-files/2011-06/NOT_BROCH_15A.pdf.

33 For documentation of the installation at Guangdong Museum of Art, and a full list of participating artists, see www.maap.org.au/exhibition/maap-gdm0a/. 
34 The conference Moving Image Cultures in Asian Art (26-28 August 2016) was convened by Chaitanya Sambrani (ANU School of Art) and Olivier Krischer (CIW), with the support of the ANU College of Art and Social Sciences. See www.soa.anu.edu.au/event/conference-moving-image-cultures-asian-art. Zhang's keynote lecture, titled 'Text and Context', and the subsequent Q\&A session are online: www.youtube.com/watch? $v=i T u 7 e 2 g n-G g$.

35 In 2012, at MAAP SPACE, in Brisbane, an expansive ten-metre-wide by twenty-two-metre-long warehousestyle, darkened exhibition space was dedicated to this work.

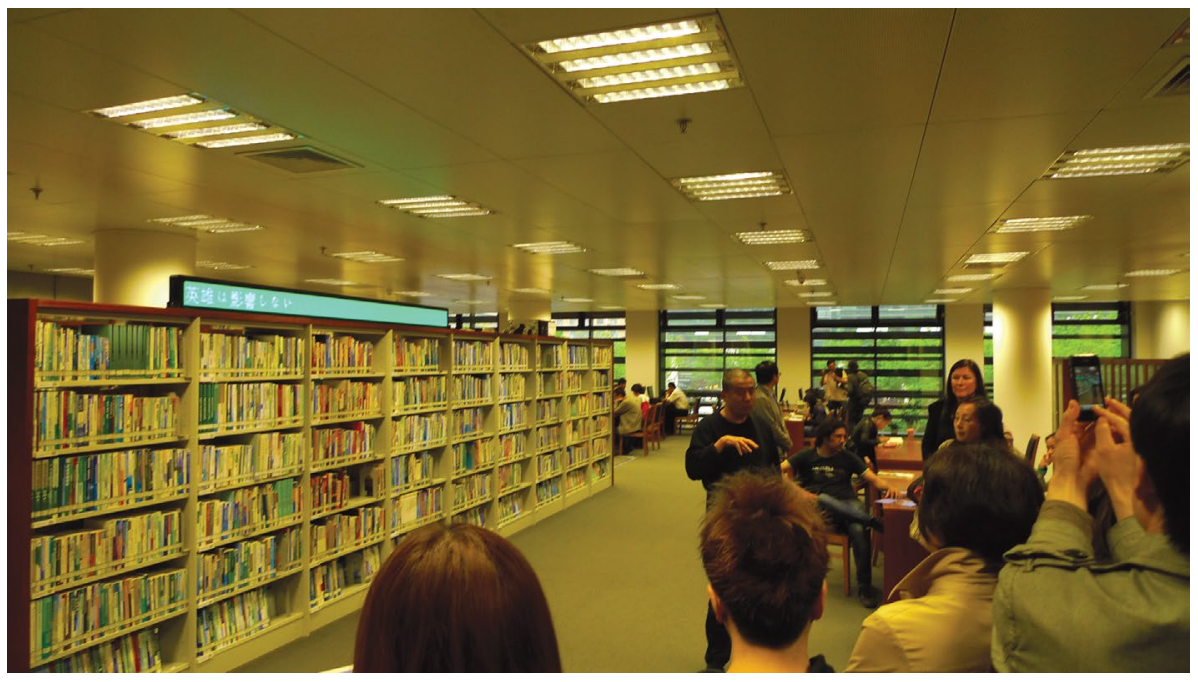

At the opening of Light from Light exhibition, Zhang Peil talks about his work Standard Translation to the audience at the National Library of China in 2011.

在中国国家图书馆举办的“光源自光”展览开幕式上张培力向观众讲解他的作品《标准翻译》。 


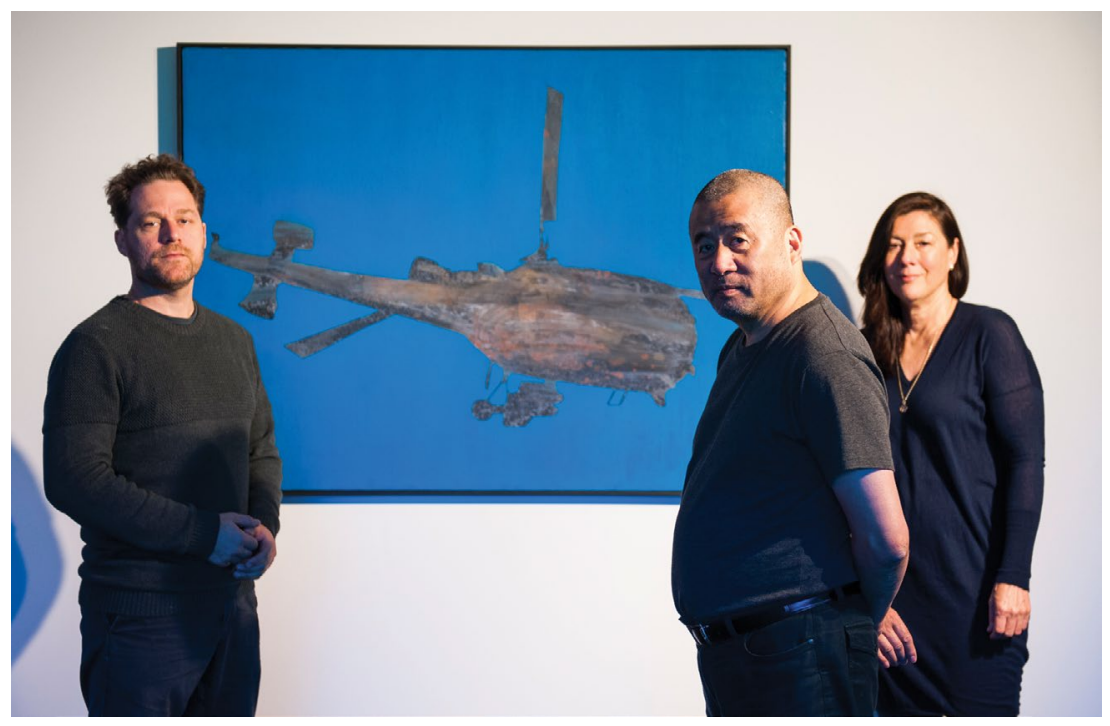

Olivier Krischer and Kim Machan with artist Zhang Peili in front of Flying Machine (1994). Photograph by Elesa Kurtz / The Canberra Times; courtesy The Canberra Times.

柯惟, 金曼与艺术家张培力于《飞行器》（1994）前。 


\title{
1990年以来中澳新媒体艺术的策展思考
}

\author{
金曼 \\ Kim Machan
}

张培力的画作《飞行器》（1994年）捐赠予澳大利亚中华全球研究中心的消息, 非 常引人注目。这不仅是因为那段时期张培力作画的数量极少, 而且这幅画之前从未 展出过, 据说早已被毁坏。 ${ }^{1}$ 另外, 使这件作品更为独特的是, 它是艺术家在转向专 注于录像和电子媒介之前的最后画作之一, 因此该画成为其实践中的重要过渡性标 记。因此, 在这幅画抵达堪培拉之前, 大家对准备工作已胸有成竹。围绕这幅画的上 下文, 展览 “张培力: 从绘画到录像” 启用了几件著名的录像艺术作品, 创作时间 远至早于此画六年完成的录像, 近至2012年的作品。

作为是次展览的铺垫, 我希望讲述我早期在中国, 作为一个录像和媒体艺术策展人的 艺术交流和经历。虽然, 这决非是完整或系统性的描述, 但它试图勾勒出背景, 并提 醒我们，展览不仅仅是临时的事件或产物：它是分享对话与情谊的休礊之地。在此聚 焦张培力的实践，不单是为了分享他的艺术成就，同时也是一种抵挡遗忘的对策，唤 起我们业已忽视的那段中澳之间艺术交流的历史。某种程度上, 这也解释了“张培 力：从绘画到录像” 中的作品最终如何布展成型; 之前中国的大型博物馆项目如何在 澳大利亚与新的、蓬勃的和颇具挑战性的策展项目对接; 中澳之间的艺术和艺术家交 流如何稳步前行; 以及, 如何在新的语境与新的重复中, 解读像张培力这样的艺术家 的现有作品。

我第一次在展览中接触张培力的作品是在 1999 年布里斯班昆士兰艺术馆举办的 第三届亚太三年展 (APT)。当时张培力的绘画实践已被搁置五年。其参展作品 《快3, 慢3, 快4, 慢4》(1999年) 显示了他对于媒介和主题的取向是雕塑性 的、冷酷的, 和质疑的。2 走进八个显示器围成的圈内, 这让人有一种强烈的体验, 也迅速把我带回到中国的观念录像艺术实践领域。早期, 中国录像和媒体艺术实践 并不常见, 不仅是在海外, 在国内也是如此。想通过展览观看录像艺术, 机会少之 甚少, 于是, 参观工作室并建立艺术家圈子, 成为进入该领域的最佳方式。在澳大利 亚, 偶尔有些罕有的机会看到张培力最早期的一些录像作品。例如, 1993年, 悉尼 
当代艺术博物馆举办的 “毛走向波普” 展示了张培力的单频录像《（卫）字3号》 （1991年）及其早期的录像装置《作业一号》（1992年）。3 之后是1998年乔纳 森- 沃金斯 (Jonathan Watkins) 策划的悉尼双年展, 展出了其三频道录像装置

《进食》(1997年)。4 1997年底, 《进食》成为首件被纽约现代艺术博物馆收藏的 由中国艺术家创作的当代艺术品。5

2000年, 一个为艺术家和策展人举办的新媒体艺术大师班在布里斯班召开, 让大家 可以交流意见, 展示作品并发展合作机会。 ${ }^{6}$ 张培力并未参与, 但另一位从事观念录 像与装置艺术的中国艺术家王功新前来参加。掌握着中国艺术和艺术家的第一手资 料, 王功新尽显其批评性取向和圈内人身份。对于国内新兴的“新媒体”现象, 包括 张培力的作品及其应邀组建杭州中国美术学院新媒体系的消息, 王功新兴奋难掩。布 里斯班的华裔澳大利亚艺术家白浦的参与也大大促进了这良好关系的发展。当语言或 沟通不甚明晰时, 白浦跟进交流并促进项目发展, 让双方达成清晰的理解, 并建立了 信任的基础。

王功新于2000年6月回到北京, 他邀请当时的中国新进策展人皮力为MAAP的年度 艺术节策划录像项目, 并将于三个月后在布里斯班发电站现场艺术中心开幕。 ${ }^{7}$ 皮 力很快将他选择的单频录像与交互式CD-ROM作品运到了布里斯班。让人惊叹的是, 超过一半的作品是当年完成的, 有些甚至是展览前几周创作的。大多数作品是首次 在中国境外放映。单频作品包括：崔岫闻的《女士们》（2000年）; 蒋志的《飞 吧，飞吧》（1997年）; 杨福东的《城市之光》（2000年）; 邱志杰的《乒兵》 （2000年）; 冯晓颖的《码根码》（2000年）; 胡介鸣《与情景有关》（1999 年）; 乌尔善的《身体》（2000年）; 王功新的《飞》（1999年）和《卡拉 $O K 》 （ 2000$ 年）。现在看来, 更令人印象深刻的, 或许是交互式CD-ROM作品, 比如, 邱志杰的《西方》（2000年）、陈劭雄的《街景（3）》（1999年）和石 青的《七》（2000年）, 这些作品在今天都很少见。在布里斯班, 这些不同类别的 VHS 录像带、迷你DV 录像带和CD-ROM光盘被编辑。虽然, 按照今天的标准, 这 些电子文件略显笨重, 但录像的便携性是革命性的, 并且让很多作品可以在中国以 外的地区展出, 这很好地响应了艺术家的欲求。

2001 年4月, 我应工作需求前往中国, 归还艺术家的作品, 并走访北京、上海和杭 州的艺术家工作室展开调研一一去杭州是专门为了与张培力会面。8 这次旅行是一个 尚好的机会, 让我可以尽可能地看到更多的展览。当时的展览大多是仓促开幕, 发 生在意想不到的场地, 有时展期仅仅是一两天。文化部刚颁布法令, 要求所有地方 当局严厉打击 “影响社会秩序、公共道德以及人民身心健康” 的展览和表演。9 当时 的政治氛围颇为紧张, 尤其是在北京, 因为那一年正是国家主席的十年领导权从江 泽民转移到胡锦涛手上。 
在北京, 我第一次见到了皮力, 还有许多在布里斯班参展的艺术家。除了归还作品, 应王功新的邀请, 我在“藏酷新媒体艺术中心” 展示了澳大利亚录像作品。10“藏 酷” 的入口是朝阳区三里屯的一家甚具现代纽约风格的餐厅, 穿过咖啡馆、酒吧和餐 厅, 一个剧场里常见的落地帘隔出了一个单独、隐蔽而又风格十足的长形房间。玻璃 墙采用氧化铁和钢梁加固, 以支撑玻璃夹层, 从底层往上看, 可以让人迷失方向。这 是一个高度活跃的场所, 用于举办展览、讲座和出版发布; 国内外的策展人、艺术 家、理论家、作家和实验音乐人都参与其中。这些来自国内外的访客, 一般是突然到 访, 因而在地的艺术家和兴趣人士会被临时召集，与他们一起参观放映或参与对话。 通过王功新的人脉播散, 观众群体与此专业高度相关, 并专注于此, 且数量惊人。北 京当代艺术圈的巨大能量和紧迫感显而易见, 而上海和杭州一一张培力生活、工作和 教学的地方一一却截然不同。北京激发了雄心勃勃的艺术家, 但也充斥着当局营造的 危险感, 上海的商业特征似乎掩盖了艺术, 而杭州及其著名的西湖, 则带有一种远观 和自治的感觉。

2001 年 4 月下旬, 我第一次到访张培力在杭州的工作室, 一起观看单频录像。现在 大概相去十七年, 但是这首次的拜访, 我依然记忆犹新: 张培力那一图书馆的作品, 按时间顺序推进, 一盒接着一盒看下去; 移动图像的产生, 全靠一个矮墩墩的CRT显 示器。它连接着普通家庭影院器材, 录像带被机器吞吐, 连续不断地播放着。我记得

《30 x 30》(1988年) 带给我的惊喜, 《(卫) 字3号》（1991年）让我入迷。作 品继续播放: 《水——辞海标准版》（1991年）、《焦距》（1996年）和《不确切 的快感 (I)》（1996年）一一用一个显示器播放这件四频道、原本需要十二台显示器操 作的作品。虽然我不会说中文, 但张培力耐心地展示了一本草稿笔记, 里面有关于如 何安装作品的图示。他非常的友好，完全不计较时间。

在张培力的工作室里观赏完作品之后, 我们去了中国美术学院, 他在那成立了一个新 媒体艺术系，同时，我被介绍给录像策展人吴美纯。11 作为联合策展人，吴美纯与邱 志杰策划了被认为是中国第一个录像艺术展1996年的“现象・影像”。之后, 吴美 纯成为学院的新媒体艺术中心的主任。12 早在北京我便知道吴美纯, 那是因为与邱 志杰的会面, 他给了我一些出版物, 是由他们译介的关于录像艺术史的重要文本。邱 志杰还提到了他们共同在杭州策划的录像艺术项目, 以及他在北京创造的越来越离谱 的“偶发艺术”，都被纳入到“后感性”的旗下。

\section{焦距}

因为这次调研之旅，2001年10月，吴美纯的录像项目参加了MAAP的展览 “超 额”，作品在艺术节的主要场地布里斯班发电站展出。13 张培力的作品《焦距》 (1996年) 也参与了展出, 就像我在他工作室中预览的那样, 以单频播放, 但通常 这是件八频道装置作品。《焦距》和杨振中的单频作品《我会死的》（2001年） 在不同的专用CRT显示器上播出, 底座支起, 在发电站河畔大楼的公共休息区内连 
续播放。王功新回到布里斯班参加开幕式, 并安装了他的两件作品: 《祷告》(2001 年), 一件在布里斯班发电站展出的单频录像投影, 以及《我的太阳》 (2001年), 一件 三频录像投影, 受朱迪思・莱特当代艺术中心的现代艺术研究所资助。

到访期间, 王功新乐观地鼓励我次年将MAAP艺术节搬到北京。他相信, 通过当地机 构的支持来实现展览是有可能的, 甚至还可以通过中国国际展览中心, 直接获取中国 政府的资助一一我们确实这样做了。我认为, 官方支持的根本原因, 在于中国政府希 望通过数字文化参与到全球经济国际转型的各个方面, 并进一步提升至先进的全球文 化。促进中国当代数字和新媒体文化的发展变得非常重要, 这就像其他技术领域的进 步, 如医药、交通、能源和太空探索。考虑到政府与艺术家之间的公开冲突, 双方都 有动力在新媒体艺术的旗帜下进行合作。张培力此时正专注于录像和新媒体平台, 正 如他在许多访谈和对话中所揭示的那样, 张对打破主观性, 探索和实验其他媒介感兴 趣。随着技术的发展, 张培力的许多录像装置被重新诠释和修改; 通过启用新的硬件 和软件产生的数字文件格式, 有的作品也得到了更新。

\section{同时播出}

张培力是最早确认参加 2002 年北京MAAP艺术节的艺术家之一, 展览“润化” 最终 于2002年10月在中华世纪坛艺术馆举办。1 4 在王功新、皮力、范迪安、李台还和王 昱东的帮助和指导下, 中国第一个重要的新媒体艺术博物馆展览和研讨会安排妥当, 这不仅扩大了展览内容, 也为艺术家提供了更好的技术支持。15 除了占地 1000 平方 米的主要展览空间, 中华世纪坛的独特之处, 在于那个由56个液晶显示器组成的巨 幕, 四层高, 十二组长, 弯成一个 31 米的弧形, 是当时中国最大的高清屏幕。意识 到了它的潜力, 张培力展开了技术实验, 重新编写了一件现有的作品, 将奥威尔式的 不和谐的声音融入一个最具象征意义的重要建筑中。 《同时播出》（2002年）在棋 盘般的屏幕墙上播放不同播音员的新闻播报。取样来自五十多个国家的新闻播报，如 交叉的影线般输出着各种语言。当他们宣播 “早安, 这是新闻” 的问候时, 通过最先 进的音响系统，涌出排山倒海般的语言和面孔。巨大的屏幕尺寸，令人眼花缭乱，怪 里怪气，并非预示着什么美好。而在其两年前的原作品《同时播出》（2000年）中, 则由二十六个面向内侧的显示器组成一个圆圈, 新闻播报员的问候环绕着观众。张培 力的作品经常采用连环格式, 无论是空间上的圆形还是长形, 时间上的循环往复还是 线性, 他的规则是去解构和重构语言、意象和意义, 并循环往复。他在中华世纪坛的 作品也不离其宗。 
在北京的正式开放期间, 我应邀给文化部的官员们进行导览, 但令人意料不到的 是, 其后陆续来了一波又一波的其他官员。我记得, 每次都有 6 到 8 人前来参加导 览, 有来自通讯部的、科学部的、卫生部的和运输部的等等。这还真是一个绝佳的文 化外交机会, 只不过, 我们没有被知会这些政府高层领导人员会参加导览, 由此很可 惜地导致了澳大利亚同僚的缺席。

要了解北京的展览环境, 我们有必要了解当地的文化政治现状。当时, 中国政府通过 文化部密切操控公共性的展览, 要求国营机构提交详细申请, 提供描述所有参展艺术 家及其作品的图像和文字, 然后才能批准展览。16 众所周知, 政府对艺术表达的敏 感, 在北京最为强烈; 南方城市的文化活动, 如上海、杭州和广州, 享受着稍微宽松 的条件。2002年的亚太多媒体艺术节“润化”代表了一个重要时刻，因为它能够让 艺术作品进入一级政府认可的展览空间，这大大扩展了中国公认的艺术实践界限。毕 竟, 这是在江泽民当权期间建造的纪念性建筑, 并由他在1999年12月31日的午夜之 前亲自揭幕，让中华世界坛内的庆祝活动成为了国内外的焦点。

张培力那整墙的高清显示器, 是展览中大量实验性数字媒体作品中的一件。另一个使 用同一面墙的是邵志飞（Jeffrey Shaw）等人的《生活之网》（2002年），作品通 过扫描观看者的手这一交互过程，在56屏的显示器上生成计算出的图像序列。17而 在中国的博物馆环境中看到的第一个现场互联网作品, 由卡尔斯鲁厄的ZKM、名古 屋的ISEA和圣保罗的 Emoção art.ficial呈现。王蓬的作品《拨打13641041729》 (2002年), 以不同的网络技术取向, 邀请观众拨打相同的手机号码, 从而激活数据 投影仪, 它悬挂在博物馆里王蓬的葫芦形雕塑上方。当这个号码被拨打时, 一系列 日常中国街道和风景景象被投射到雕塑中, 来电者也能听取艺术家的录音信息, 包 括通过信息库回复的邀请消息。另外，20件让人沉浸其中的深具挑战性的作品均来 自亚洲和澳大利亚，参与的项目来自澳大利亚移动影像中心（ACMI）、D-Lux媒体 艺术、Asia link和香港的录映太奇。18 所有的艺术作品都预先提交给文化部审批同 意, 除了一个无意中包含了法轮功练习示例图的录像。展览开幕时, 大家都觉得难 以置信, 毕竟, 在四年前, 国家型的展览是不能也不会偏离大家所公认的艺术类型, 如, 挂墙上的绘画或带底座的雕塑。19

尽管不是在公立空间或博物馆举行, 一个来自澳大利亚的新媒体艺术展, 绕过了官方 审查程序, 找到了一个创新平台。1999年, 琳达・华莱士（Linda Wallace）20 在 澳大利亚驻华大使馆里举办了一场名为 “探索” 的新媒体艺术展, 有六名澳大利亚 艺术家参展。展览受到大使馆文化参赞安东尼・泰勒 (Anthony Taylor) 与澳大利 亚画廊主布朗・华莱士 (Brian Wallace) $)^{21}$ 的支持, 以及白杰明的鼓励。展览在大 使馆的大厅举行, 需要邀请函方可进入。慕名前来的中国观众反复用着别人用过的 票据。22 在国家公立机构之外, 装置、表演、媒体和录像艺术继续推进着边界, 最 终在2001年初引发了另一次正式的政府镇压。23 尽管有这些限制, 并导致挑畔性的 
展览被关闭, 艺术家被逮捕或拘留, 但我们还是被告知, 政府会用不同的视角来审 视应用于当代艺术的新数字技术的观念。在举办了2002年的北京亚太新媒体艺术展

《润化》及其研讨会之后, 中华世纪坛继续强调新媒体艺术, 并与策展人、教育家和 艺术家张尔联合策划了2004年6月的 “首届北京国际新媒体艺术展暨论坛” , 我参加 了论坛并介绍了关于MAAP的项目。24

2005年3月, 张培力应现代艺术研究所所长迈克尔 - 斯勒林（Michael Snelling）的 邀请, 回到澳大利亚展出两件作品。25 在布里斯班, 张培力在研究所的主要画廊空间 安装了两个单频投影《台词》（2002年）和《遗言》（2003年）。这也促成了我们 另一次见面的机会, 但我们没有任何具体的项目; 虽然我们经常在中国和国际上不同 展览中相遇，距另一个具体的项目计划，还有四年之久。

\section{标准翻译}

2010 年, 我邀请张培力在澳大利亚和中国选定的公共图书馆环境下制作特定场地的 装置, 作为 “光源自光” 项目（2010-2012年）的一部分。项目分别邀请了五位澳 大利亚和中国艺术家, 作品安装在布里斯班昆士兰州立图书馆、上海图书馆、中国 国家图书馆、中国美术馆、以及杭州公共图书馆。26 在考虑并回应了各图书馆之后, 张培力决定使用新推出的硬件和软件修改《标准翻译》（2008年）, 这最初是一个 4:3的单频录像作品。在同一标题下, 为这件新作品一 《标准翻译》(2008-2010 年)一一他订做了 2 米长的 LED 显示器, 将早期的录像观念转换为文本在上面滚动, 这种媒介让人想起官方新闻头条和引导性的股市信息。2 7 工作和展览让张培力奔波往 返于澳大利亚的场地和中国的展馆之间，也使得大家的交流和会面愈加频繁。

在布里斯班的昆士兰州立图书馆, 张培力的显示器取代了Tim Fairfax阅览室原有的 红色LED咨询显示器。在北京的中国国家图书馆, 展期间的作品达到了极好的效果, 即使正常的书柜被打乱, 这让研究者在拖延或思考的间隙内获得启发。2010年9月, 因为这个项目, 张培力来到布里斯班, 与昆士兰州立图书馆的技术人员合作, 参加研 讨会并完善安装。他还前往北京, 参加中国国家图书馆的开幕, 并前往上海和杭州 图书馆指导安装工作。澳大利亚艺术家珍妮・博茨尔 (Janet Burchill) 、珍妮佛 · 麦卡利（Jennifer McCamley）、白浦（Paul Bai）、尤金·卡切西欧（Eugene Carchesio）、乔伊斯・亨特丁（Joyce Hinterding）、大卫・海因斯（David Haines) 、阿切 - 莫尔 (Archie Moore) 和奥地利艺术家乔瑟夫 · 斯昭 (Josef Strau）前往上海进行安装, 随后出席了张培力协助下的, 由杭州中国美术学院组 织的展览研讨会。艺术家们参观了学校, 并在研讨会上展示了他们的个人作品和实 践。此外, 我做了一个策展概述, 到场的听众主要是学生。28 
因为展览 “光源自光”，为期两年的往返周折让我们有了长期接触, 张培力和我讨论 了在澳大利亚举办个展的可能性。2012年, MAAP在布里斯班开设了一个新的展览 场地 MAAP SPACE, 张培力同意其个展作为空间的开幕展。2012年8月, 他再次 回到布里斯班指导作品的安装, 并慷慨地在展览的前几天做了个艺术家谈话。张培 力的个展包括了我们2001 年首次见面时的重要作品一一 《30x30》（1988年)、 《(卫) 字3号》(1991 年) 和《不确切的快感 (I)》 (1996年)一一以及《标准翻 译》(2008-2010年), “光源自光”的委托创作作品, 以后存放在布里斯班。 同时, MAAP SPACE还展出了一件新作《Q \& A \& Q》(2012年), 这也是它第一次 在画廊或博物馆中展出。

\section{$Q \& A \& Q$}

这个同步的双频录像装置被投射到画廊的一个角落, 左侧屏幕投影出一个正在审讯的 警察的头部和上身，右侧是对两名被拘留的轻犯进行连续的审问。一张简单的硬板登 与端正地垂直于墙面上的屏幕形成三角状。这可让观众坐在中间, 隔着没有出镜的桌 子, 见证着滔滔不绝的问与答。这段录像由两台放在桌子上的摄影机录制, 镜头朝相 反方向分别摄录着审问中的每个人。张培力典型的中立取向, 试图尽可能逼真地呈现 这种交换。他将这件作品描述为 “具有相反身份认同的两人之间的问答对话被安装好 的设备纪录着”，并确认 “这既不是CCTV，也不是摆拍的摄录”。29 这不是一场历 经预演的戏剧，但也不是秘密的拍摄，所 以，审问的警察和被审问的嫌疑人都带有一 定程度的自我意识。张培力认为, 这是实现一种现实主义的更好方式。30

展览在2012年底结束, 次年5月, 我携带着一包DVD前往中国, 亲自把东西返还给 张培力。当我把这一大摞的作品递给他, 再次感谢他的参与和不懈的支持时, 张培力 将作品推还给我说: “你应该把它们带回去, 你可能需要它们。”对我来说, 这是一个 令人难忘的举动, 代表了信任的同时, 也是开展另一个项目的挑战。这些作品之后被 安全地存放起来, 直到与柯惟(Olivier Krischer)讨论起在澳大利亚中华全球研究中心 (CIW) 举办展览时, 这些重要的作品再次激起了大家的灵感。

2013 年到 2015 年间, 在中华全球研究中心的展览之前, 张培力与我也有其它 的合作。“海陆空一一重返录像艺术的空间性”（2014-2015年）是一个巡回展, 先是得到了华侨城当代艺术中心上海馆(上海OCAT)的支持, 再而是首尔Artsonje 中心、广州的广东美术馆、悉尼的国立艺术学院画廊、格里菲斯大学美术馆与布里 斯班的 MAAP SPACE。策展理念聚焦于理解录像的雕塑性与空间性, 以20世纪 60-70年代观念艺术实践中的国际( “全球”) 对话为参考点, 从而选定了澳大利亚、 中国和其他国际艺术家。31 该展览于2014年2月在首尔开幕, 得到了 Art Sonje 中心的金宣廷以及当地卫星商业艺术画廊空间的支持, 稍后于当年4月巡展于上海 OCAT。在此项目的拓展阶段, 张培力已经参与其中。他的参展作品是《直线距离 一公里》 (2010年)。这是一个双频录像装置, 两人手拿摄像机, 沿着一条直线向 
对方行走, 相遇的距离是一公里。额外的电控原件发出标准录音信号, 从而逐步增强地干 扰扭曲视听, 最终产生愈发让人眼盲耳狵的白噪声。32 2015年5月, 展览在广州广东美 术馆拉下帷幕。33

\section{中华全球研究中心举办的 “张培力：从绘画到录像”}

现在, 我们回到这个 “分享对话的休㮩之处”：这次在中华全球研究中心举办的展览, 灵感 来于一幅原以为早已毁坏的画作。2016年8月，因为这幅画的出现，我和同仁们相聚于堪 培拉, 并再次与张培力相会, 这段深刻而丰富的友谊让大家受益匪浅。康兰丝、白杰明、 姜苦乐、罗清奇（Claire Roberts）、白浦、古婷婷、柯惟以及我自己（金曼）参加了开幕 式, 为张培力的展览欢庆。张培力也为同期举行的、与澳大利亚国立大学艺术学院合作举办 的“亚洲艺术中的移动影像文化”会议做了主题发言。 其发言由小说家兼文化评论家贾佩 琳（Linda Jaivin）绝妙地翻译成英文。34

在中华全球研究中心的展览中, 首先映入眼窝的是《不确切的快感(I)》(1996年)。这件作 品自 1996年在巴黎Galerie de France首展以来, 曾以多种形式呈现。这件六频作品在十 二个显示器中重复, 总被特别地调适到符合展览语境的状态。35 在中华全球研究中心, 八 个显示器被置于画廊里, 四个在外面, 画廊入口的玻璃门并没有产生任何分隔效果。穿行于 画廊边缘之里外, 这件作品延伸至画廊外面的前厅, 突出了张培力录像艺术作品中的空间体 验。画廊内外 《不确切快感(I)》的物理位置激活了对其他边界的感知, 画廊朝北的玻璃墙与 开阔的绿地相接, 澳大利亚的原生灌木、繁茂的桉树和沙利文溪的相连, 这些四周相随的景 观与作品相互呼应。随着前厅蜿蜒在地的显示器, 观者的视线被牵引至画廊内的其它作品。 从前厅开始, 地上十二个显示器播放着标志性的搔挠皮肤的影像, 背景中可见《标准翻译》 那色彩绚丽的文本在滑动, 高高地嵌在深灰的后墙上。

从入口处便可一眼看出, 《水一一辞海标准版》(1991年) 中新闻播音员背后那灼眼的 “蓝幕”，作品靠底座支起，对着左边的墙，也间接面对着油画《飞行器》（1994年）。 画中硬边的直升机形象被相似的蓝色包裹, 艺术家让中国官方媒体的影像与其三年后的画 作之间产生了明显联系。虽然, 《飞行器》中的直升机形象看似是引自报纸上的照片或电 视影像, 但其身份并不明朗。张培力再次提出关于现实在电视和印刷媒体中如何被表现的问 题,虽然丧失了实用信息和原有的主观性，每件作品似乎都采用了官方媒体的模板。这幅画 作挂在天花板较低的空间, 与灰墙形成对比, 画作周围的墙面被涂成白色, 进而增强了蓝色 的亮度。仔细观察画作的表面, 可以识别出用于表达 “飞行器” 形状的笔触和遮罩技巧。在 我看来，与他的《水中的泳者》（1985年)、《休止音符》(1985年）中的萨克斯风演奏者 或《X?》系列手套画（1986-1987年）相比，这件作品中的画笔处理并不寻常。在这件 
作品中, 直升机的形状并非平坦或常见的轻薄, 而是通过非正式的滴和泼的画迹的累 积, 来表现一种抽象的冲动。为了重设 “中立” 的主体性, 这些笔触遮罩了直升机的 轮廓形象, 并克制地将画布四周绘至平坦的蓝色。这是张培力绘画实践中使用的一种 罕见技巧。

穿过《不确切的快感(I)》的显示器和亮色的《飞行器》, 一个底座上不起眼的24英寸 CRT显示器将大家的视线进一步引入画廊, 《30 x 30》（1988年）映入眼窝, 这 也是张培力使用录像媒介创作的第一件作品。音频设置为低音, 没有耳机, 与附近的

《水一一辞海标准版》锃铭有力的声音共处一堂。为了忠实呈现作品创作时的技术条 件, 和念及画廊有限的空间, 我们特别选择在大小适中的显示器来播放这些作品。视 线右转, 观者可见画廊尽头处放着另一台24英寸CRT显示器, 播放着《(卫)字3号》 (1991年)。这件作品没有声音, 因此, 它与近处展览入口的《Q \& A \& Q》没有产 生任何冲突。但事实上, 反复冲洗已被冲洗过的鸡与《问与答与问》中重复发生的审 讯, 都切中了关于控制与服从的主题。《(卫) 字3号》的底座和显示器由一堵墙支 撑, 墙后便是最后一个展厅。两个简单的木椅面向墙角, 《Q \& $A \& Q 》$ 的双频投影 于此, 音箱循环播放着音频。最后一件作品完善了展览环境, 它让张培力绘制的《飞 行器》更顺利地进入到堪培拉的语境。

由此, 展览 “张培力: 从绘画到录” 的源起可以追溯跨越三十载, 它涉及了一群艺术 家、策展人和学者, 并激起了一波波非标准化的会议、展览、以及与张培力和其他同 仁的交流。我们之间相互交叉的故事，既职业又私人，它们共同对文化的交流、合作 和友谊献上了特别的阐述。

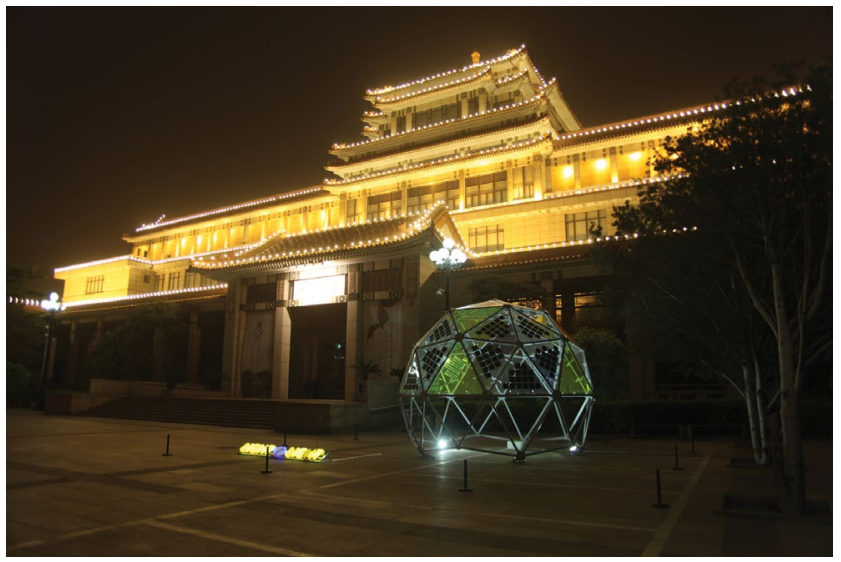

Janet Burchill \& Jennifer McCamley, Light from Light, 2010, self-powered geodesic dome, custombuilt photovoltaic panels, acrylic, neon and aluminium frame. Image courtesy Kim Machan.

简内特 ·菠其奥与詹妮弗·麦克凯莫莉, 《光源自光》, 2010年, 自供电网格球顶, 定制光伏板块, 丙烯, 霓虹灯, 铝合 金框架。 
1. 黄专和王景编: 《张培力艺术工作手册》, 广州: 岭南出版社, 2008年, 第184-185页。

2. 从舞池外的八个固定摄像位置拍摄, 这件装置展示了舞厅内的场景, 并在圆形结构内部的八个显示器上播放, 图像自动跳 转。1999年, 受昆士兰美术馆亚太三年展委托创作并被收藏; 2017年, 在芝加哥艺术学院举办的个展 “张培力: 录像·重复” 中, 这件作品也有展出。

3. 当代艺术博物馆 (MCA) 举办的 “毛走向波普：1989之后的中国”，是在悉尼举办的规模较小的“后89中国新艺术” 巡回展。“后89中国新艺术” 展览主要由北京评论家栗宪庭和香港画廊主张颂仁策划组织, 1993年1月至2月在香港大会堂及 香港艺术中心举行, 作为香港艺术节的一部分。悉尼是举办该展览的第一个海外目的地, 然后是墨尔本、温哥华和美国的五个 场馆。作家周思（Nicholas Jose）曾在1987年至1990年间担任驻北京澳大利亚大使馆的文化顾问, 之后在悉尼担任MCA 的策展顾问。

4. 乔纳森 · 沃金斯 (Jonathan Watkins) 是悉尼大学毕业的艺术史学者, 在批评家黄笃的帮助下, 于1997-98年前往中国展开 对艺术家的研究。基于沃金斯邮件2017年7月11日。

5. 此后, 纽约现代艺术博物馆馆长芭芭拉 ·伦敦（Barbara London）于1997年9月访问中国, 为此, 她创建了一个网络博客, 名 为 《Stir-fry: 一位录像策展人从中国的来信》。参阅 www.adaweb.com/context/stir-fry/index 1.html。纽约现代艺术博物馆于 1998年10月28日至1999年2月2日举办了展览 “张培力：进食”，随后于1998年收藏了《（卫）字3号》（1991年）。

6. 澳大利亚艺术与技术网络 (ANAT) 主任阿曼达 $\cdot M \cdot$ 克劳利 (Amanda McDonald Crowley) 于2000年5月至6月初组 织了此次活动，参与者包括来自欧洲、北美、亚洲和澳大利亚的58位艺术家、教师和策展人。笔者是受邀策展人之一。王功新 是唯一来自中国的艺术家; 其他亚洲艺术家包括来自印度的Shilpa Gupta和Monica Narula，来自孟加拉国的Partha Pratim Sarker，以及来自印度尼西亚的Hartanto和Christiawan。

7. 2010 年, 皮力在北京的中央美术学院完成了博士学位。2005年至2012, 他是北京博而励画廊的策展人和画廊主。2012年7 月, 担任香港 $\mathrm{M}+$ 视觉文化博物馆的高级策展人。

8. 为了降低空运关税, 这是当时归还作品的更可取方式。

9. 汤伟峰（Thomas J. Berghuis）：《中国行为艺术》，香港：东八时区出版社，2006年，第274-275页。

10. 自2000年8月 10 日展出顾德新的装置而揭幕, 藏酷新媒体艺术中心已运营了8个月。关于展览的项目与方案可参见中心自出 版的书册《藏酷欢迎你》（2002年），这也是2002年光州双年展的特别项目。书中的项目由王功新与皮力策划，王功新、皮力 与林天苗为此撰文。

11. 1996年9月14日, “现象・影像”在中国美术学院的展览空间举办, 十五位艺术家参展, 大多作品为多频装置。。

12. 2001 年, 张培力在中国美术学院成立新媒体艺术中心。第一批学生于2003年入学, 2004年至2005年, 张培力致力于课程 发展。第一批学生毕业于2006年。

13. 关于其他展览作品和项目, 参见 www.maap.org.au/exhibition/maap-2001-excess。

14. 由MAAP与其它机构联合主办, 包括：中华世纪坛博物馆、北京歌华集团、中国国际展览中心、中央美术学院以及澳大利亚 驻华大使馆。

15. 除了独立艺术家王功新; 皮力之后是北京中央美术学院的助理研究员, 范迪安任副院长; 李台还是中国国际展览中心的艺术 顾问; 王昱东是中华世纪坛艺术馆的副馆长。澳大利亚驻华大使馆的文化关系专员Linda Hao也提供了协助。

16. 获得文化部许可的手续一直延续至今, 事实上, 随着技术的进步, 审查的范围已扩大到包括向公众开放的更多场所。

17. 其它参与 《生活之网》的艺术家有：迈克尔 ·格雷切 (Michael Gleich) 、本特 · 林特曼 (Bernd Lintermann) 、托 森 · 贝尔纳 (Torsten Belschner)、劳伦斯 · 沃伦 (Lawrence Wallen) 、曼弗雷德 $\cdot$ W · 普洛特格 (Manfred WolffPlottegg)。林特曼与普洛特格来到北京安装作品, 并参加了论坛及其他相关活动。

18. 关于在中华世纪坛艺术馆与藏酷新媒体艺术中心的展出作品、录像、驻地及相关活动, 参见 www.maap.org.au/ publications/\#moi。

19. 1989年中国美术馆举办 “中国现代艺术展”之后, 当局严禁在国立美术馆内展出当代艺术, 直到1998年解禁。

20. 琳达 ·华莱士 (Linda Wallace) 当时是澳洲国立大学的在读博士研究生, 这个展览是她研究的成果。关于华莱士作为录 像艺术家和策展人的实践, 以及对于亚洲的研究, 参见 www.machinehunger.com.au/new.html, and www.scanlines.net/ person/linda-wallace。网页包含录像视频。 
21. 布朗·华莱士（Brian Wallace）1984年首次前往北京, 1985年重返, 之后在北京工作和学习, 并在中央美术学院取得艺 术史学位。1991年, 他创立了北京第一个外籍人士主理的当代艺术画廊, 红门画廊最早设立在中国世贸大酒店内, 之后迁入明城 墙遗址公园里的东南瞭望塔。

22. 纽约的911袭击之后, 宣布了“反恐战争”，这种轻松进入澳大利亚大使馆的方式有所改变。展览详情见:

www.machinehunger.com.au/probe。

23. 汤伟峰: 《中国行为艺术》, 香港: 东八时区出版社, 2006年, 第274-275页。

24. 张尔当时在纽约帕森斯设计学院任教。2008年, 该展览演变为“北京国际新媒体双年展”，并在馆长范迪安的支持下迁移 至中国美术馆。MAAP与该项目合作，展示了澳大利亚艺术家Stelarc和Transmute Collective，以及来自韩国的金起徹（Kim Ki-chul) 和来自新加坡的保罗・林肯 (Paul Lincoln) 的作品。2011年, 它成为国际新媒体艺术三年展。2014年, MAAP 再次与 “Thingworld” 合作，支持澳大利亚艺术家韦德・玛丽劳斯基（Wade Marynowsky），凯斯·阿姆斯（Keith Armstrong）, 劳伦斯·英格利什（Lawrence English），比查·葛敏巴切（Petra Gemeinbach）和罗博·桑德（Rob Saunders) 的项目。

25. 这次邀请通过MAAP和白浦的协助顺利达成。

26. 该公共艺术项目于2013年荣获澳大利亚文化部首届“澳大利亚亚洲艺术奖一一视觉艺术奖”。参见 www.maap.org.au/ publications/\#Ifl。

27. LED信息使用2010年版的谷歌翻译生成，以耀目的颜色显示出来，让人难以阅读和理解。比如，原文是中国谚语 “好汉不吃 眼前亏”，意思是教人在战斗中面对失败应有撤退的智慧，但软件把它翻译成英文 “英雄不吃即时的损失”。通过这种方式，谚 语的意思因翻译成超过二十五种语言而被系统性地歪曲。

28. 同年年初, 北京的博而励画廊带着这件作品参加了瑞士巴塞尔艺术博览会。同年8月从MAAP撤展之后, 作品又参加了2012 年10月的上海双年展。

29. 张培力在 2012 年第九届上海双年展画册中的艺术家陈述, 这也是上海双年展第一次在上海当代博物馆举办。参见李向阳、许 江等编: 《重新发电：第九届上海双年展——城市馆》, 上海：上海当代博物馆, 2012年, 第138页。

30. 同上, 第138页。

31. 参展艺术家包括：简 ·迪贝兹（Jan Dibbets, 荷兰)、杨振中、王功新、王蓬、朱加、张培力（中国）、金守子、郑然斗、 沈铁雄（韩国）、白浦（Paul Bai）、劳伦・布伦凯特（Lauren Brincat）、芭芭拉・坎贝尔（Barbara Campbell）、德拉 克 ·克雷克勒（Derek Kreckler）、克雷格·沃尔什（Craig Walsh, 澳大利亚）、乔凡尼 - 欧佐拉（Giovanni Ozzola, 意大 利），祖坚·包华（João Vasco Paiva, 葡萄牙/香港）、希尔帕・库普塔（Shilpa Gupta, 印度）、黑默 ·佐伯尼格（Heimo Zobernig, 奥地利) 。策展人金曼, 参见 www.maap.org.au/exhibitions。展览画册可线上汶览: www.maap.org.au/ publications/\#Iss。

32. 这件作品由展览 “不仅仅是时间：张培力和朱加” 委托订制, 在美国洛杉矶REDCAT艺术中心举办。但在展览手册 中, 作品名为《一条线, 一千米》。参见 www.redcat.org/sites/redcat.org/files/gallery/linked-files/2011-06/NOT_ BROCH_15A.pdf。

33. 关于广东美术馆的装置与参展艺术家名单，参见 www.maap.org.au/exhibition/maap-gdm0a/。

34. 研讨会议 “亚洲艺术中的移动影像文化”（2016年8月26-28日）由澳大利亚国立大学艺术学院的查坦亚・萨布拉尼 (Chaitanya Sambrani) 与澳洲国立大学中国全球研究中心的柯惟主持，并受澳洲国立大学艺术与社科学院的支持。参见 www. soa.anu.edu.au/event/conference-moving-image-cultures-asian-art。张培力的讲座名为 “语言与语境”，之后的问答环 节视频可见 www.youtube.com/watch?v=iTu7e2gn-Gg。

35. 2012年, 布里斯班的MAAP SPACE为此作品特地安排了个10米宽22米长的昏暗的仓库型空间。 
This text is taken from Zhang Peili: From Painting to Video, edited by Olivier Krischer, published 2019 by ANU Press, The Australian National University, Canberra, Australia.

doi.org/10.22459/ZP.2019.07 